\title{
Large Scales of Hydrangea macrophylla Using Tissue Culture Technique
}

\author{
Azza M.S. Arafa ${ }^{1}$, A.A. Nower ${ }^{2} *$,Samia S. Helme ${ }^{1}$ and H.A. Abd-Elaty ${ }^{1}$ \\ ${ }^{1}$ Department of Ornamental Horticulture, Faculty of Agriculture, Cairo University Egypt \\ ${ }^{2}$ Department of plant biotechnology, Genetic Engineering and Biotechnology \\ Research Institute (GEBRI), University OF Sadat City (usc), Egypt \\ *Corresponding author:
}

\begin{tabular}{|c|c|}
\hline & A B S T R A C T \\
\hline $\begin{array}{l}\text { Ke y w o r d s } \\
\text { Hydrangea } \\
\text { macrophylla, } \\
\text { in vitro, BA, GA3, } \\
\text { micropropagation, } \\
\text { acclimatization. }\end{array}$ & $\begin{array}{l}\text { Hydrangea (Hortensia) is a highly popular ornamental plant for garden decoration, and } \\
\text { now it is commercially produced for cut flower branches. The aim of this study was to set } \\
\text { up a protocol for large scale for in vitro propagation of Hydrangea macrophylla, for this } \\
\text { purpose two type of explant (shoot tip and node) were sterilized and the best percentage of } \\
\text { survival explants }(40 \% \text { ) was obtained when explants immersed for } 20 \text { min in } 1.0 \text { or } 1.5 \% \\
\text { NaOCl. For in vitro multiplication, Murashige and Skoog medium supplemented with } 1.0 \\
\text { mg/l BA and } 2.0 \mathrm{mg} / \mathrm{l} \mathrm{Kin} \mathrm{was} \mathrm{the} \mathrm{best} \mathrm{treatment} \mathrm{on} \mathrm{shoot} \mathrm{number.} \mathrm{Using} \mathrm{GA3} \mathrm{at} 1.0 \mathrm{mg} / \mathrm{l}\end{array}$ \\
\hline Article Info & $\begin{array}{l}\text { was a marked increase in plant length when compared with zero level (control). During the } \\
\text { rooting stage, the medium containing } 4.0 \mathrm{mg} / \mathrm{l} \text { IAA with charcoal gave the longest plantlet }\end{array}$ \\
\hline $\begin{array}{l}\text { Accepted: } \\
\text { 04x April } 2017 \\
\text { Available Online: } \\
\text { 10 May } 2017\end{array}$ & $\begin{array}{l}\text { and the highest number of leaves, while NAA at } 1.0 \mathrm{mg} / \mathrm{l} \text { without charcoal gave the } \\
\text { highest number of roots and the longest root was found at } 2.0 \mathrm{mg} / \mathrm{l} \text { IAA without charcoal. } \\
\text { The longest plant }(6.17 \mathrm{~cm}) \text { was achieved when peat moss: per lite }(2: 1 \mathrm{v} / \mathrm{v}) \\
\text { acclimatization mixture was used compared with other mixtures. }\end{array}$ \\
\hline
\end{tabular}

\section{Introduction}

The family Hydrangeaceae includes mainly woody plants and comprises 17 genera and about 170 species. Hydrangea macrophylla is one of the most well-known species in the genus and is known by the name of Hortensia (Orozco-Obando, 2005). In most species the flowers are white, in $H$. macrophylla they can be blue, red, pink, light purple, or dark purple, the color depends on the soil pH (Savona et al., 2012). Hydrangea macrophylla subsp. has been widely cultivated as a garden and potted plant. In addition, cut flower cultivars have been developed Common cultivated species is grown widely in gardens (Schiappacasse et $a l .$, 2014). In commercial practice, hydrangea is propagated either by seeds or stem cuttings.
Each method has its own drawbacks. Seed plants vary and don't allow the propagation of desirable forms, Leaf cuttings occupy considerable space during propagation because of their very large size. Moreover, plants from cuttings are slow to establish and lack good basal branching. Tissue culture methods for vegetative propagation of plants have become increasingly important (Thomas et al., 1987).

Tissue culture method is part of biotechnology that is used for massive propagation especially for horticulture crops and ornamental plants. So many factors such as growth regulator, plant and explants type, 
environmental condition (temperature, light) influence organogenesis and in vitro multiplication. It seems that among these factors, growth regulators have the most effect on plant in vitro micropropagation (Jain, 2002). In the last 20 years, few papers were published focusing to Hydrangea in vitro propagation; Sebastian et al., (1987) reported the first micropropagation protocol for Hydrangea quercifolia Bart. The influence of thidiazuron (TDZ) on in vitro shoot proliferation was demonstrated by Preece and Ledbetter (2003) and Ledbetter and Preece (2004), low concentrations of this growth regulator induced a low number of long shoots; high concentrations of TDZ ensured many short adventitious shoots. Abou Dahab (2007) set up a protocol for micropropagation of Hydrangea macrophylla for commercial production. To optimize in vitro adventitious shoot regeneration in Hydrangea macrophylla Thunb. 'Nacthtigall', experiments on salts compositions (MS or B5 - full or half strength), on different cytokinins applied (BAP or TDZ or m-Top) and onto the propagations way (Solid Medium or Temporary Immersion System or Permanent Immersion System) were performed by Doil et al., (2008). In 2012, Sacco and co-authors reported that Hydrangea quercifolia 'Snow Queen' showed an efficient in vitro propagation aptitude combined with a good propagation rate when culturing the explants onto agarised MS medium with BA 0.25 $\mathrm{mg} / \mathrm{L}$.

The aim of this research was to set up a protocol for large scale micropropagation of Hydrangea macrophylla. This purpose was done by studying the effect of sodium hypochlorite (NaOCL) for different times on Sterilization of explants type, effect of cytokinin type (BA or Kin) and explant type on micropropagation, effect of different auxins type (IAA, IBA or NAA) and charcoal addition on rooting and effect of growing media on adaptation of plantlets in greenhouse.

\section{Materials and Methods}

\section{Plant materials}

The mother plants were grown naturally at the open field condition at Institute of Genetic Engineering and Biotechn ology. University of Sadat City, Egypt, shoot tips and nodes were used as explants

\section{Experimental treatments}

\section{Sterilization of explants}

Different explants (shoot tip and nodes) of one year old plants of Hydrangea macrophylla were washed under a running water for one hour. After washing the explants were dipped in mercuric chloride $(\mathrm{HgCl} 2)$ at concentration of $0.1 \%$ for 5 minutes then were rinsed in sterilized distilled water.

Chemical disinfectant Clorox ( $\mathrm{NaOCl} 5.25 \%)$ were used for shoot tips and nodes surface sterilization with various concentration $(0.5,1.0,1,52.0$ and $2.5 \%)$ of sodium hypochlorite (NaOCL) for different times (10, 15 and 20 minutes). Tween 20 (polyoxythylenesorbitan monolaurate) was used as a wetting agent (one drop / $100 \mathrm{ml}$ ). Sterilized explants were rinsed three times with sterilized distilled water to remove all traces of sterilizing substances, and cultured in $25 \mathrm{ml}$ of culture medium. Murashige and Skoog (1962) nutrient medium was used as a basal medium supplemented with $30 \mathrm{~g} / \mathrm{l}$ sucrose and $7 \mathrm{~g} / \mathrm{l}$ agar. This experiment consisted of 15 treatments, 3 replicates / treatment, 10 explants / replicate. After 15days of incubation the following characters were estimated: survival percentage, mortality percentage and contamination percentage. 


\section{Initial source of explant}

Vigorous shoots of Hydrangea macrophylla were multiplied in vitro onto Murashige and Skoog (MS), 3\% sucrose, supplemented with $0.25 \mathrm{mg} / \mathrm{L}$ of 6-benzyladenine (BA) and agarized with $8 \mathrm{~g} / \mathrm{L}$ of technical Agar according to the protocol suggested by Sacco et al., (2012).

\section{Multiplication stage}

Effect of different levels of BA and Kin combination on multiplication from shoot tip or nodal segments of Hydrangea macrophylla in vitro culture

The explants (shoot tip $(0.5 \mathrm{~cm})$ or nodal segment (1 node)) were cultured on full strength MS medium supplemented with the following concentration of $\mathrm{BA}(0.0,1.0,2.0$ and $3.0 \mathrm{mg} / \mathrm{l}$ ) combined with one of the following rates of kin $(0.0,0.5,1.0$ and 2.0 $\mathrm{mg} / \mathrm{l})$.This experiment consisted of 16 treatments, 5 replicates (gar / 2 explant). After 45 days of incubation the following parameters were estimated shoot number /explant, leaf number/explant, shoot length $(\mathrm{cm})$, fresh weight $(\mathrm{g})$

Effect of different GA3 concentration on growth from shoot tip of Hydrange a macrophylla in vitro culture

In this experiment, shoot tip as explants were cultured on MS medium supplemented with different concentration of GA3: 0.0, 0.2, 0.4, 0.6 and $1.0 \mathrm{mg} / \mathrm{l}$. This experiment consisted of 5 treatments, 5 replicates / treatment. After 45 days of incubation the following parameters were estimated: shoot length $(\mathrm{cm})$ and leaf number/explant

\section{Rooting stage}

Effect of auxins type (IAA, IBA or NAA) and charcoal addition on rooting stage of Hydrangea macrophylla in vitro culture

In order to induce an efficient and functional in vitro root system, the shoots $(2 \mathrm{~cm})$ were cultured on full strength MS medium only and supplemented with indol acetic acid (IAA), indol butyric acid (IBA) or naphthalen acetic acid (NAA) at the same concentrations $(0.5$, $1.0,2.0$ and $4.0 \mathrm{mg} / \mathrm{l})$ with or without activated charcoal (AC) $1 \mathrm{~g} / \mathrm{l}$. This experiment consisted of 26 treatment, for each treatment, 15 replect ( 3 jars with 5 explants each were considered). After 45 days plantlet length $(\mathrm{cm})$, leaf number/ plantlet, plantlet fresh weight $(\mathrm{g})$, root number / plantlet and root length $(\mathrm{cm})$ were recorded

\section{Culture condition}

All of this experiments the $\mathrm{pH}$ of the medium was adjusted to 5.8 and autoclaved at $1210 \mathrm{C}$ for 20 minutes. All the cultures were incubated in growth room at $25 \pm 20 \mathrm{C}$ temperature under 16 hours photoperiod using cool-white fluorescent lamp.

\section{Acclimatization stage}

Effect of different growing media on adaptation of plantlets Hydrangea macrophylla in greenhouse

Plantlet ( $3 \mathrm{~cm}, 4$ leaves) which produced in vitro were washed under tap water to remove agar from the roots which might be a source of contamination, then transplanted to plastic pots $(6 \mathrm{~cm})$ containing of different growing media containing a mixture $(\mathrm{v} / \mathrm{v})$ of 
1- Peat moss only

2- Peat moss + perlite (1:1)

3- $\quad$ Peat moss + perlite $(2: 1)$

4- Peatmoss + perlite $(3: 1)$

5- Peatmoss + vermiculite (1:1)

In order to maintain high humidity in culture environment, the pots were covered with a light plastic cover. The plantlet was gradually exposed to normal greenhouse conditions, after 45 days of the following parameters were estimated: Plantlet length $(\mathrm{cm})$, leaf number/ plantlet, root number/ plantlet and root length $(\mathrm{cm})$.

\section{Statistical analysis}

All of the experiments were carried out as a factorial experiment at $5 \%$ probability level. Data obtained were statistically analyzed using MSTAT software program (MSTAT Development Team, 1989) for comparing among least significant difference (LSD).

\section{Results and Discussion}

\section{Starting stage}

Effect of $\mathrm{NaOCl}$ concentration and period time on sterilization of tow explants of Hydrangea macrophylla cultured in vitro.

\section{Shoot tip explants}

Results demonstrated in table (1) indicate that, the best concentration of $\mathrm{NaOCl}$ was 1.5 $\%$ which gave $(30 \%)$ survived explants, no mortality $(0 \%)$ was observed when explants were treated by $0.5,1.0$ and $1.5 \%$. with increase of $\mathrm{NaOCl}$ concentration, the percentage of contaminated explants was decreased. On the other hand, the data indicated that increasing the soaking period of explants increased the survival percentage of

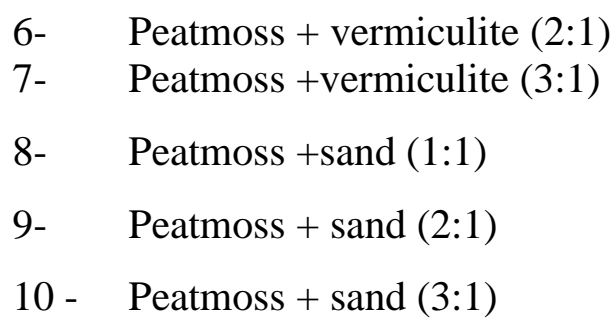

explants. Soaking the explants for 20 min was the best time for the highest percentage of survival $(30 \%)$, highest percentage of mortality $(16 \%)$ and the lowest percentage of contamination $(54 \%)$. The data of the interaction between the concentration of $\mathrm{NaOCl}$ and the time of soaking indicated that the best percentage of survival explants $(40 \%)$ was obtained when explants immersed for 20 $\min$ in 1.0 or $1.5 \% \mathrm{NaOCl}$ and for $15 \mathrm{~min}$ in $1.5 \% \mathrm{NaOCl}$. The highest mortality percentage $(50 \%)$ was observed when explants were treated by $2.5 \% \mathrm{NaOCl}$ for 20 min and the lowest contamination percentage (30\%) was obtained when explants immersed for 10 or $20 \mathrm{~min}$ in $2.5 \% \mathrm{NaOCl}$.

\section{Node explants}

Data in table (2) showed that the highest survival percentage $(26 \%)$ was observed when explants were treated by $1.5 \% \mathrm{NaOCl}$. The highest mortality percentage and the lowest contamination percentage (40\%) and $(53.33 \%)$ respectively were obtained when explants were treated by $2.5 \% \mathrm{NaOCl}$. Increasing the soaking period of explants increased the survival percentage of explants. Soaking the explants for $20 \mathrm{~min}$ was the best time for the highest percentage of survival (22 $\%)$, highest percentage of mortality $(19.33 \%)$ and the lowest percentage of contamination $(58.76 \%)$.

The data of the interaction between the concentration of $\mathrm{NaOCl}$ and the time of soaking indicated that the best percentage of survival explants $(30 \%)$ was obtained when 
explants immersed for $20 \mathrm{~min}$ in 1.0, 1.5, 2.0 $\% \mathrm{NaOCl}$ and for $15 \mathrm{~min}$ in $1.5 \% \mathrm{NaOCl}$. The highest mortality percentage $(50 \%)$ was observed when explants were treated by 2.5 $\% \mathrm{NaOCl}$ for $20 \mathrm{~min}$ and the lowest contamination percentage $(40 \%)$ was obtained when explants immersed for $20 \mathrm{~min}$ in $2.0 \% \mathrm{NaOCl}$.

This result may be due to the liability of plant tissue of Hydrangea macrophylla to excessive surface sterilization with mercuric chloride (MC) which has a lysis effect on microbial cells, as stated by Abou Dahab (2007) reported that the results of explant indicated that the highest percentage of contamination free explants $(100 \%)$ was obtained by using chlorox at $50 \%$ plus mercuric chloride (MC) at the concentration $0.2 \%$.

\section{Multiplication stage}

The results shown that the multiplication of Hydrangea macrophella was successfully achieved by culture on MS medium supplemented with concentration of BA and Kin.

\section{Effect of BA and Kin concentration on shoot tips of Hydrangea macrophella}

Table (3) showed that for BA concentrations, culture on MS medium containing $1.0 \mathrm{mg} / \mathrm{l}$ $\mathrm{BA}$, the mean higher number of shoots (4.45) and leaf (42.70) giving significant effect as compared with 0.0, 2.0, $3.0 \mathrm{mg} / \mathrm{l}$ BA. For Kin concentrations the mean higher number of shoots (3.75) and leaf (36.20) were found on MS medium containing $1.0 \mathrm{mg} / \mathrm{l} \mathrm{Kin.} \mathrm{The}$ interaction between the different concentrations of BA and Kin showed that the best concentration was $1.0 \mathrm{mg} / \mathrm{l} \mathrm{BA}$ and 2.0 $\mathrm{mg} / \mathrm{l} \mathrm{Kin}$ on shoot number giving (6.60), while the best number of leaves was (56 leaf/explant) at $1.0 \mathrm{mg} / \mathrm{l} \mathrm{BA}$ with $1.0 \mathrm{mg} / \mathrm{l}$ Kin. While data in table (4) showed that the highest values for shoot length $(2.95 \mathrm{~cm})$ had been obtained from the control treatment, the largest fresh weight $(3.65 \mathrm{~g})$ were found when MS medium containing $3.0 \mathrm{mg} / \mathrm{l} \mathrm{BA}$. For shoot length, there were insignificant differences between all the different concentrations of Kin but the longest shoot was $(2.80 \mathrm{~cm})$ at $2.0 \mathrm{mg} / \mathrm{l} \mathrm{Kin}$, while the best fresh weight was $(3.11 \mathrm{~g})$ at $2.0 \mathrm{mg} / \mathrm{l} \mathrm{Kin}$. The interaction showed that for shoot length, there were insignificant differences between all the different concentrations but the longest shoot was $(3.3 \mathrm{~cm})$ had been obtained from the control treatment. The best concentration for fresh weight $(4.40 \mathrm{~g})$ was $3.0 \mathrm{mg} / \mathrm{l} \mathrm{BA}$ with $2.0 \mathrm{mg} / \mathrm{l} \mathrm{Kin}$.

\section{Effect of BA and Kin concentration on nodes explant of Hydrangea macrophella}

Data in table (5) show that $1.0 \mathrm{mg} / \mathrm{l}$ was the best concentration of BA on shoot number, leaf number, they were recorded (8.00) and (79.60) respectively and $0.5 \mathrm{mg} / \mathrm{l}$ of Kin was the best concentration for both measurements, the highest number of shoots was (6.75) and biggest leaf number was (69.60).A combination between BA and Kin was positively significant, the highest number of shoots (11) was obtained when MS medium supplemented with $1 \mathrm{mg} / \mathrm{l} \mathrm{BA}$ and $2.0 \mathrm{mg} / \mathrm{l}$ Kin, while the best concentration for leaf number (110.0) was $2.0 \mathrm{mg} / \mathrm{l} \mathrm{BA}$ with 1.0 $\mathrm{mg} / \mathrm{l} \mathrm{Kin}$.

Results presented in table (6) show that the longest shoot $(3.00 \mathrm{~cm})$ was obtained at zero level of BA and the best fresh weight was $(5.38 \mathrm{~g})$ at $1.0 \mathrm{mg} / \mathrm{l} \mathrm{BA}$.

For shoot length, there were insignificant differences between all the different concentrations of Kin but the longest shoot was $(2.90 \mathrm{~cm})$ at $0.5 \mathrm{mg} / \mathrm{l} \mathrm{Kin} \mathrm{and} \mathrm{the} \mathrm{best}$ fresh weight $(4.65 \mathrm{~g})$ had been obtained at the same concentration $0.5 \mathrm{mg} / \mathrm{l}$ Kin. For the interaction, results showed that MS medium 
without any growth regulators was best treatment for shoot length $(3.20 \mathrm{~cm})$, while addition of $1.0 \mathrm{mg} / \mathrm{l} \mathrm{BA}$ and $0.5 \mathrm{mg} / \mathrm{l} \mathrm{Kin}$ to MS medium gave the highest fresh weight (7.43 g).

This result agrees with a number of published papers on rooting of Hydrangea macrophylla Doil et al., (2008) reported that 6benzyladenine (BA) rather than TDZ could induce higher regeneration rates for Hydrangea macrophylla. Feng Liu (2011) reported that, the highest frequency of leaf explants producing shoots $(77 \%)$ and the highest mean number of shoots per explant (2.1) were observed on B5 medium supplemented with $2.25 \mathrm{mg} / \mathrm{l} \mathrm{BA}$ and $0.1 \mathrm{mg} / \mathrm{l}$ IBA. Sacco et al., (2012) found that, in the multiplication phase the BA, at any concentration, induced the highest multiplication rate (over 7 shoots/explant) and the highest cluster fresh weight the shoot height was not affected by the cytokinin used in each treatment (data not shown). Very good quality explants were obtained using kinetin but the multiplication rate was not suitable for a commercial production.

\section{Effect of GA3 concentration on plant length and leaf number}

Results in table (7) indicate that in general, the addition of GA3 to the medium led to increase in plant length. Increasing the GA3 to $1.0 \mathrm{mg} / \mathrm{l}$ there was a marked increase in shoot length when compared with zero level (control), it was found $(4.12 \mathrm{~cm})$ and there were significant differences between it and different concentrations, while GA3 at 0.6 $\mathrm{mg} / \mathrm{l}$ gave the highest number of leaves when compared with control.

\section{Rooting stage}

Effect of auxins type (IAA, IBA or NAA) and charcoal addition on rooting stage of Hydrangea macrophylla in vitro. Results presented in table (8) show that, using IAA at $4.0 \mathrm{mg} / \mathrm{l}$ gave the longest plantlet $(5.52 \mathrm{~cm})$ and highest number of leaves (12.47), while the best plantlet fresh weight was (1.46 g) at $2.0 \mathrm{mg} / \mathrm{l} \mathrm{NAA}$. There was insignificant effect for charcoal addition on plantlet length, while using charcoal gave biggest number of leaves (11.70) and using medium without charcoal produced the best values of plantlet weight $(1.05 \mathrm{~g})$. Data of interaction between different concentrations and charcoal addition showed that using $4.0 \mathrm{mg} / \mathrm{l}$ IAA with charcoal gave the longest plantlet $(5.52 \mathrm{~cm})$ and the highest number of leaves (12.8), $2.0 \mathrm{mg} / \mathrm{l} \mathrm{NAA}$ with charcoal was the best treatment for plantlet fresh weight $(1.63 \mathrm{~g})$.

Table.1 Effect of different $\mathrm{NaOCl}$ concentration and times on survival, mortality and contamination percentages of Hydrangea macrophylla shoot tips in vitro culture after 2 weeks

\begin{tabular}{|c|c|c|c|c|c|c|c|c|c|c|c|c|}
\hline \multirow{4}{*}{$\begin{array}{c}\mathrm{NaOCl} \\
\text { concentration }\end{array}$} & \multicolumn{12}{|c|}{ Shoot tip } \\
\hline & \multirow{2}{*}{\multicolumn{3}{|c|}{$\begin{array}{l}\text { Survival \% } \\
\text { Time (min) }\end{array}$}} & \multirow{3}{*}{$\begin{array}{c}\text { Mean } \\
\text { (A) }\end{array}$} & \multirow{2}{*}{\multicolumn{3}{|c|}{$\begin{array}{c}\text { Mortality \% } \\
\text { Time (min) }\end{array}$}} & \multirow{3}{*}{$\begin{array}{c}\text { Mean } \\
\text { (A) }\end{array}$} & \multirow{2}{*}{\multicolumn{3}{|c|}{$\frac{\text { Contamination \% }}{\text { Time (min) }}$}} & \multirow{3}{*}{$\begin{array}{c}\text { Mean } \\
(\mathrm{A})\end{array}$} \\
\hline & & & & & & & & & & & & \\
\hline & 10 & 15 & 20 & & 10 & 15 & 20 & & 10 & 15 & 20 & \\
\hline 0.5 & 10.00 & 30.00 & 30.00 & 23.33 & 0.00 & 0.00 & 0.00 & 0.00 & 90.00 & 70.00 & 70.00 & 76.67 \\
\hline 1.0 & 10.00 & 10.00 & 40.00 & 20.00 & 0.00 & 0.00 & 0.00 & 0.00 & 90.00 & 90.00 & 60.00 & 80.00 \\
\hline 1.5 & 10.00 & 40.00 & 40.00 & 30.00 & 0.00 & 0.00 & 0.00 & 0.00 & 90.00 & 60.00 & 60.00 & 70.00 \\
\hline 2.0 & 20.00 & 30.00 & 20.00 & 23.33 & 10.00 & 20.00 & 30.00 & 20.00 & 70.00 & 50.00 & 50.00 & 56.67 \\
\hline 2.5 & 30.00 & 30.00 & 20.00 & 26.67 & 40.00 & 30.00 & 50.00 & 40.00 & 30.00 & 40.00 & 30.00 & 33.33 \\
\hline Mean (B) & 16.00 & 28.00 & 30.00 & & 10.00 & 16.00 & 74.00 & & 62.00 & 54.00 & & \\
\hline $\begin{array}{c}\text { L.S.D at 5\% A } \\
\text { B } \\
\text { AB }\end{array}$ & & & $\begin{array}{l}32 \\
44 \\
41\end{array}$ & & & & $\begin{array}{l}64 \\
37 \\
77\end{array}$ & & & & $\begin{array}{l}.02 \\
31 \\
.81\end{array}$ & \\
\hline
\end{tabular}


Table.2 Effect of different $\mathrm{NaOCl}$ concentration and times on survival, mortality and contamination percentages of Hydrangea macrophylla nodes in vitro culture after 15 days

\begin{tabular}{|c|c|c|c|c|c|c|c|c|c|c|c|c|}
\hline \multirow{4}{*}{$\begin{array}{c}\mathrm{NaOCl} \\
\text { concentration }\end{array}$} & \multicolumn{12}{|c|}{ Node } \\
\hline & \multirow{2}{*}{\multicolumn{3}{|c|}{$\begin{array}{l}\text { Survival \% } \\
\text { Time (min) }\end{array}$}} & \multirow{3}{*}{$\begin{array}{l}\text { Mean } \\
\text { (A) }\end{array}$} & \multirow{2}{*}{\multicolumn{3}{|c|}{$\begin{array}{c}\text { Mortality \% } \\
\text { Time (min) }\end{array}$}} & \multirow{3}{*}{$\begin{array}{c}\text { Mean } \\
\text { (A) }\end{array}$} & \multirow{2}{*}{\multicolumn{3}{|c|}{$\begin{array}{c}\text { Contamination \% } \\
\text { Time (min) }\end{array}$}} & \multirow{3}{*}{$\begin{array}{l}\text { Mean } \\
\text { (A) }\end{array}$} \\
\hline & & & & & & & & & & & & \\
\hline & 10 & 15 & 20 & & 10 & 15 & 20 & & 10 & 15 & 20 & \\
\hline 0.5 & 0.00 & 0.00 & 20.00 & 6.66 & 0.00 & 0.00 & 0.00 & 0.00 & 100.00 & 100.00 & 80.00 & 93.33 \\
\hline 1.0 & 20.00 & 20.00 & 30.00 & 23.33 & 0.00 & 0.00 & 16.67 & 5.55 & 80.00 & 80.00 & 53.00 & 71.11 \\
\hline 1.5 & 20.00 & 30.00 & 30.00 & 26.67 & 0.00 & 0.00 & 0.00 & 0.00 & 80.00 & 70.00 & 70.00 & 73.33 \\
\hline 2.0 & 0.00 & 20.00 & 30.00 & 16.66 & 10.00 & 20.00 & 30.00 & 20.00 & 90.00 & 60.00 & 40.00 & 63.33 \\
\hline 2.5 & 10.00 & 10.00 & 0.00 & 6.66 & 40.00 & 30.00 & 50.00 & 40.00 & 50.00 & 60.00 & 50.00 & 53.33 \\
\hline Mean (B) & 10.00 & 16.00 & 22.00 & & 10.00 & 10.00 & 19.33 & & 80.00 & 74.00 & 58.67 & \\
\hline $\begin{array}{c}\text { L.S.D at 5\% A } \\
\text { B } \\
\text { AB }\end{array}$ & \multicolumn{4}{|c|}{$\begin{array}{c}7.00 \\
5.42 \\
12.12\end{array}$} & \multicolumn{4}{|c|}{$\begin{array}{l}5.19 \\
4.02 \\
8.99\end{array}$} & \multicolumn{4}{|c|}{$\begin{array}{l}8.66 \\
6.71 \\
15.01\end{array}$} \\
\hline
\end{tabular}

Table.3 Effect of different BA and Kin concentrations on shoot and leaf number of Hydrangea macrophylla shoot tips in vitro culture after 45 days

\begin{tabular}{|c|c|c|c|c|c|c|c|c|c|c|}
\hline \multirow{4}{*}{$\begin{array}{c}\text { BA } \\
\mathbf{m g} / \mathbf{l}\end{array}$} & \multicolumn{10}{|c|}{ Shoot tip } \\
\hline & \multirow{2}{*}{\multicolumn{4}{|c|}{$\begin{array}{c}\text { Shoot number /explant } \\
\text { Kin mg/l }\end{array}$}} & \multirow{3}{*}{$\begin{array}{c}\text { Mea } \\
\text { n } \\
\text { (A) }\end{array}$} & \multirow{2}{*}{\multicolumn{4}{|c|}{$\frac{\text { Leaf number/explant }}{\text { Kin } \mathbf{~ m g / l}}$}} & \multirow{3}{*}{$\begin{array}{c}\text { Mean } \\
\text { (A) }\end{array}$} \\
\hline & & & & & & & & & & \\
\hline & 0.0 & 0.5 & 1.0 & 2.0 & & 0.0 & 0.5 & 1.0 & 2.0 & \\
\hline 0.0 & 1.00 & 1.20 & 1.20 & 1.80 & 1.30 & 15.60 & 17.60 & 15.60 & 18.40 & 16.80 \\
\hline 1.0 & 2.80 & 2.80 & 5.60 & 6.60 & 4.45 & 30.00 & 34.00 & 56.00 & 50.80 & 42.70 \\
\hline 2.0 & 3.40 & 2.00 & 5.00 & 1.80 & 3.05 & 43.60 & 24.80 & 47.60 & 19.60 & 33.90 \\
\hline 3.0 & 5.00 & 2.60 & 3.20 & 4.00 & 3.70 & 50.40 & 35.20 & 25.60 & 42.00 & 38.30 \\
\hline Mean (B) & 3.05 & 2.15 & 3.75 & 3.55 & & 34.90 & 27.90 & 36.20 & 32.70 & \\
\hline $\begin{array}{c}\text { L.S.D at 5\% A } \\
\text { B } \\
\text { AB }\end{array}$ & \multicolumn{5}{|c|}{$\begin{array}{l}0.5315 \\
0.5315\end{array}$} & & \multicolumn{3}{|c|}{$\begin{array}{l}2.685 \\
5.370\end{array}$} & \\
\hline
\end{tabular}

Table.4 Effect of different BA and Kin concentrations on shoot length and fresh weight of Hydrangea macrophylla shoot tips in vitro culture after 45 days

\begin{tabular}{|c|c|c|c|c|c|c|c|c|c|c|}
\hline \multirow{4}{*}{$\begin{array}{c}\text { BA } \\
\mathrm{mg} / \mathrm{l}\end{array}$} & \multicolumn{10}{|c|}{ Shoot tip } \\
\hline & \multirow{2}{*}{\multicolumn{4}{|c|}{ Shoot length $(\mathrm{cm})$}} & \multirow{3}{*}{$\begin{array}{c}\text { Mean } \\
\text { (A) }\end{array}$} & \multicolumn{4}{|c|}{ Fresh weight(g) } & \multirow{3}{*}{$\begin{array}{c}\text { Mean } \\
\text { (A) }\end{array}$} \\
\hline & & & & & & \multicolumn{4}{|c|}{ Kin mg/l } & \\
\hline & 0.0 & 0.5 & 1.0 & 2.0 & & 0.0 & 0.5 & 1.0 & 2.0 & \\
\hline 0.0 & 3.30 & 3.00 & 2.70 & 2.80 & 2.95 & 1.49 & 1.52 & 1.71 & 2.20 & 1.73 \\
\hline 1.0 & 3.10 & 2.90 & 2.80 & 2.80 & 2.90 & 2.26 & 2.72 & 4.15 & 3.73 & 3.21 \\
\hline 2.0 & 2.40 & 2.80 & 2.70 & 3.00 & 2.72 & 4.14 & 2.66 & 3.58 & 2.14 & 3.13 \\
\hline 3.0 & 2.00 & 2.40 & 2.50 & 2.60 & 2.37 & 4.33 & 3.30 & 2.55 & 4.40 & 3.65 \\
\hline Mean(B) & 2.70 & 2.77 & 2.67 & 2.80 & & 3.06 & 2.55 & 3.00 & 3.11 & \\
\hline $\begin{array}{c}\text { L.S.D at 5\% A } \\
\text { B } \\
\text { AB } \\
\end{array}$ & \multicolumn{5}{|c|}{$\begin{array}{c}0.5190 \\
\text { N.S } \\
1.038\end{array}$} & \multicolumn{5}{|c|}{$\begin{array}{l}0.1108 \\
0.1108 \\
0.2216\end{array}$} \\
\hline
\end{tabular}


Table.5 Effect of different BA and Kin concentrations on shoot number and leaf number of Hydrangea macrophylla nodes in vitro culture after 45 days

\begin{tabular}{|c|c|c|c|c|c|c|c|c|c|c|}
\hline \multirow{4}{*}{$\begin{array}{c}\text { BA } \\
\mathrm{mg} / \mathrm{l}\end{array}$} & \multicolumn{10}{|c|}{ Node } \\
\hline & \multirow{2}{*}{\multicolumn{4}{|c|}{$\begin{array}{c}\text { Shoot number /explant } \\
\text { Kin mg/l }\end{array}$}} & \multirow{3}{*}{$\begin{array}{c}\text { Mean } \\
\text { (A) }\end{array}$} & \multirow{2}{*}{\multicolumn{4}{|c|}{$\begin{array}{c}\text { Leaf number/explant } \\
\text { Kin mg/l } \\
\end{array}$}} & \multirow{3}{*}{$\begin{array}{c}\text { Mean } \\
(\text { A) } \\
\end{array}$} \\
\hline & & & & & & & & & & \\
\hline & 0.0 & 0.5 & 1.0 & 2.0 & & 0.0 & 0.5 & 1.0 & 2.0 & \\
\hline 0.0 & 2.00 & 4.40 & 3.60 & 5.80 & 3.95 & 23.60 & 40.80 & 34.80 & 50.40 & 37.40 \\
\hline 1.0 & 7.80 & 8.40 & 4.80 & 11.00 & 8.00 & 80.40 & 90.00 & 45.60 & 102.4 & 79.60 \\
\hline 2.0 & 7.00 & 9.40 & 9.60 & 4.80 & 7.70 & 63.60 & 94.00 & 110.0 & 48.00 & 78.90 \\
\hline 3.0 & 5.80 & 4.80 & 5.40 & 3.40 & 4.85 & 57.20 & 51.60 & 56.00 & 44.00 & 52.20 \\
\hline Mean (B) & 5.65 & 6.75 & 5.85 & 6.25 & & 56.20 & 69.10 & 61.60 & 61.20 & \\
\hline $\begin{array}{c}\text { L.S.D at } 5 \% \text { A } \\
\text { B } \\
\text { AB }\end{array}$ & \multicolumn{5}{|c|}{$\begin{array}{l}0.6637 \\
0.6637 \\
1.327\end{array}$} & \multicolumn{5}{|c|}{$\begin{array}{l}3.479 \\
3.479 \\
6.958\end{array}$} \\
\hline
\end{tabular}

Table.6 Effect of BA and Kin concentrations on shoot length and fresh weight of Hydrangea macrophylla nodes in vitro culture after 45 days

\begin{tabular}{|c|c|c|c|c|c|c|c|c|c|c|}
\hline \multirow{4}{*}{$\begin{array}{c}\text { BA } \\
\mathrm{mg} / \mathrm{l}\end{array}$} & \multicolumn{10}{|c|}{ Node } \\
\hline & \multicolumn{4}{|c|}{ Shoot length $(\mathrm{cm})$} & \multirow{3}{*}{$\begin{array}{c}\text { Mean } \\
\text { (A) }\end{array}$} & \multicolumn{4}{|c|}{ Fresh weight (g) } & \multirow{3}{*}{$\begin{array}{c}\text { Mean } \\
\text { (A) }\end{array}$} \\
\hline & \multicolumn{4}{|c|}{ Kin mg/l } & & \multicolumn{4}{|c|}{ Kin mg/l } & \\
\hline & 0.0 & 0.5 & 1.0 & 2.0 & & 0.0 & 0.5 & 1.0 & 2.0 & \\
\hline 0.0 & 3.20 & 2.90 & 3.10 & 2.80 & 3.00 & 1.65 & 2.59 & 2.19 & 3.06 & 2.37 \\
\hline 1.0 & 3.10 & 3.10 & 2.90 & 2.80 & 2.97 & 5.35 & 7.43 & 3.13 & 5.61 & 5.38 \\
\hline 2.0 & 2.40 & 2.80 & 2.70 & 2.90 & 2.70 & 5.08 & 5.03 & 6.20 & 3.60 & 4.98 \\
\hline 3.0 & 2.30 & 2.80 & 2.7 & 2.60 & 2.60 & 4.31 & 3.54 & 3.50 & 2.87 & 3.55 \\
\hline Mean (B) & 2.75 & 2.90 & 2.85 & 2.77 & & 4.10 & 4.65 & 3.75 & 3.78 & \\
\hline $\begin{array}{c}\text { L.S.D at } 5 \% \text { A } \\
\text { B } \\
\text { AB }\end{array}$ & \multicolumn{5}{|c|}{$\begin{array}{l}0.1920 \\
\text { N.S. } \\
0.3839\end{array}$} & \multicolumn{5}{|c|}{$\begin{array}{l}0.09952 \\
0.09952\end{array}$} \\
\hline
\end{tabular}

Table.7 Effect of different GA3 concentration on shoot length and leaf number of Hydrangea macrophylla in vitro culture after 45 days

\begin{tabular}{|c|c|c|}
\hline GA3 mg/l & Shoot length $(\mathbf{c m})$ & Leaf number/explant \\
\hline 0.0 & 1.780 & 9.760 \\
\hline 0.2 & 2.460 & 10.00 \\
\hline 0.4 & 2.700 & 10.16 \\
\hline 0.6 & 3.280 & 10.72 \\
\hline 1.0 & 4.120 & 10.16 \\
\hline L.S.D at 5\%level & 0.2072 & 0.7235 \\
\hline
\end{tabular}


Table.8 Effect of auxins type (IAA,IBA or NAA) concentrations and charcoal addition on plantlet length $(\mathrm{cm})$, leaf number/ plantlet and /shootlet fresh weight $(\mathrm{g}))$ of

Hydrangea macrophyllain rooting stage

\begin{tabular}{|c|c|c|c|c|c|c|c|c|c|c|}
\hline \multirow{3}{*}{ G.R } & \multirow{3}{*}{ Conc. } & \multicolumn{3}{|c|}{ plantlet length $(\mathbf{c m})$} & \multicolumn{3}{|c|}{ Leaf number/ plantlet } & \multicolumn{3}{|c|}{$\begin{array}{c}\text { plantlet fresh weight } \\
(\mathrm{g})\end{array}$} \\
\hline & & \multicolumn{2}{|c|}{ Charcoal g/l } & \multirow{2}{*}{$\begin{array}{l}\text { Mean } \\
\text { (A) }\end{array}$} & \multicolumn{2}{|c|}{ Charcoal g/l } & \multirow{2}{*}{$\begin{array}{l}\text { Mean } \\
\text { (A) }\end{array}$} & \multicolumn{2}{|c|}{ Charcoal g/l } & \multirow{2}{*}{$\begin{array}{c}\text { Mea } \\
\text { n } \\
(\mathbf{A})\end{array}$} \\
\hline & & 0.0 & 1.0 & & 0.0 & 1.0 & & $\mathbf{0 . 0}$ & 1.0 & \\
\hline Cont & 0.0 & 4.20 & 3.60 & 3.90 & 12.40 & 11.07 & 11.73 & 0.63 & 0.68 & 0.65 \\
\hline \multirow{4}{*}{$\begin{array}{l}\text { IAA } \\
\text { mg/l }\end{array}$} & 0.5 & 3.40 & 3.73 & 3.57 & 12.13 & 12.40 & 12.27 & 0.53 & 0.60 & 0.57 \\
\hline & 1.0 & 4.17 & 2.87 & 3.52 & 11.20 & 10.40 & 10.80 & 0.67 & 0.48 & 0.57 \\
\hline & 2.0 & 4.27 & 4.27 & 4.27 & 12.13 & 12.13 & 12.13 & 0.98 & 0.87 & 0.93 \\
\hline & 4.0 & 5.17 & 5.87 & 5.52 & 12.13 & 12.80 & 12.47 & 1.14 & 1.08 & 1.11 \\
\hline \multirow{4}{*}{$\begin{array}{l}\text { IBA } \\
\text { mg/l }\end{array}$} & 0.5 & 3.50 & 3.70 & 3.60 & 10.67 & 10.67 & 10.67 & 0.93 & 0.78 & 0.85 \\
\hline & 1.0 & 5.27 & 4.90 & 5.08 & 12.00 & 12.00 & 12.00 & 1.19 & 0.95 & 1.07 \\
\hline & 2.0 & 4.77 & 4.57 & 4.67 & 11.73 & 12.27 & 12.00 & 1.27 & 1.17 & 1.22 \\
\hline & 4.0 & 3.87 & 3.93 & 3.90 & 10.27 & 11.07 & 10.67 & 1.11 & 0.79 & 0.95 \\
\hline \multirow{4}{*}{$\begin{array}{l}\text { NAA } \\
\text { mg/l }\end{array}$} & 0.5 & 4.20 & 4.07 & 4.13 & 12.13 & 12.40 & 12.27 & 1.16 & 0.88 & 1.02 \\
\hline & 1.0 & 5.00 & 5.17 & 5.08 & 12.27 & 12.40 & 12.33 & 1.51 & 1.11 & 1.31 \\
\hline & 2.0 & 3.60 & 4.87 & 4.23 & 8.53 & 12.27 & 10.40 & 1.28 & 1.63 & 1.46 \\
\hline & 4.0 & 3.33 & 3.37 & 3.35 & 7.07 & 10.27 & 8.67 & 1.19 & 0.63 & 0.91 \\
\hline \multicolumn{2}{|c|}{ Mean (B) } & 4.21 & 4.22 & & 11.13 & \multicolumn{2}{|c|}{11.70} & 1.05 & 0.90 & \\
\hline \multicolumn{2}{|c|}{$\begin{array}{l}\text { L.S.D at 5\% levelA } \\
\text { B } \\
\text { AB }\end{array}$} & \multicolumn{3}{|c|}{0.21} & & 0.61 & & & $\begin{array}{l}0.08 \\
0.03 \\
0.11\end{array}$ & \\
\hline
\end{tabular}

Table.9 Effect of auxins type (IAA, IBA or NAA) and charcoal addition on root number/shootlet and root length $(\mathrm{cm})$ of shoots $(\mathrm{cm}$, leaf) Hydrangea macrophylla in rooting stage

\begin{tabular}{|c|c|c|c|c|c|c|c|}
\hline \multicolumn{2}{|c|}{ Treatments } & \multicolumn{3}{|c|}{ Root number / plantlet } & \multicolumn{3}{|c|}{ Root length (cm) } \\
\hline \multirow[t]{2}{*}{ Auxins } & \multirow{2}{*}{$\begin{array}{c}\text { Concentration } \\
(\mathrm{mg} / \mathrm{l})\end{array}$} & \multicolumn{2}{|c|}{$\begin{array}{c}\text { Charcoal } \\
\text { g/l }\end{array}$} & \multirow{2}{*}{$\begin{array}{c}\text { Mean } \\
\text { (A) }\end{array}$} & \multicolumn{2}{|c|}{$\begin{array}{c}\text { Charcoal } \\
\mathrm{g} / \mathrm{l}\end{array}$} & \multirow{2}{*}{ Mean (A) } \\
\hline & & 0.0 & 1.0 & & 0.0 & 1.0 & \\
\hline control & 0.0 & 3.13 & 3.20 & 3.17 & 4.60 & 3.50 & 4.05 \\
\hline \multirow{4}{*}{ IAA } & 0.5 & 2.53 & 2.93 & 2.73 & 3.40 & 2.33 & 2.87 \\
\hline & 1.0 & 3.33 & 3.47 & 3.40 & 3.77 & 1.36 & 2.56 \\
\hline & 2.0 & 4.13 & 3.67 & 3.90 & 4.80 & 4.40 & 4.60 \\
\hline & 4.0 & 4.20 & 3.87 & 4.03 & 4.67 & 4.40 & 4.53 \\
\hline \multirow{4}{*}{ IBA } & 0.5 & 4.27 & 3.07 & 3.67 & 2.23 & 2.70 & 2.47 \\
\hline & 1.0 & 5.07 & 4.27 & 4.67 & 3.57 & 4.13 & 3.85 \\
\hline & 2.0 & 5.27 & 3.93 & 4.60 & 3.93 & 4.07 & 4.00 \\
\hline & 4.0 & 2.87 & 2.87 & 2.87 & 2.87 & 2.27 & 2.57 \\
\hline \multirow{4}{*}{ NAA } & 0.5 & 4.87 & 3.40 & 4.13 & 3.13 & 2.87 & 3.00 \\
\hline & 1.0 & 5.40 & 3.93 & 4.67 & 3.47 & 4.13 & 3.80 \\
\hline & 2.0 & 3.40 & 4.87 & 4.13 & 2.97 & 4.67 & 3.81 \\
\hline & 4.0 & 2.87 & 3.00 & 2.93 & 2.03 & 2.10 & 2.07 \\
\hline \multicolumn{2}{|c|}{ Mean (B) } & 3.95 & 3.57 & & 3.50 & 3.30 & \\
\hline \multicolumn{2}{|c|}{$\begin{array}{l}\text { L.S.D at 5\% level A } \\
\text { B } \\
\text { AB }\end{array}$} & \multicolumn{3}{|c|}{$\begin{array}{l}0.37 \\
0.15 \\
0.52\end{array}$} & & $\begin{array}{l}0.3 \\
0.1 \\
0.5\end{array}$ & \\
\hline
\end{tabular}


Table.10 Effect of growing media on plant length $(\mathrm{cm})$, leaf number/ plant, root number/plant and root length $(\mathrm{cm})$ of Hydrangea macrophylla ex vitro

\begin{tabular}{|l|c|c|c|c|}
\hline \multicolumn{1}{|c|}{ Mix } & $\begin{array}{c}\text { Plant } \\
\text { length }(\mathbf{c m})\end{array}$ & $\begin{array}{c}\text { Leaf } \\
\text { number/ } \\
\text { plantlet }\end{array}$ & $\begin{array}{c}\text { Root } \\
\text { number/ } \\
\text { plantlet }\end{array}$ & $\begin{array}{c}\text { Root } \\
\text { length } \\
\text { (cm) }\end{array}$ \\
\hline Peat moss only & $\mathbf{5 . 5 0 0}$ & $\mathbf{1 0 . 0 0}$ & $\mathbf{2 4 . 3 3}$ & $\mathbf{5 . 6 6 7}$ \\
\hline Peat moss +perlite (1:1) & $\mathbf{6 . 0 0 0}$ & $\mathbf{1 . 0 0}$ & $\mathbf{5 0 . 6 7}$ & $\mathbf{7 . 3 3 3}$ \\
\hline Peat moss +perlite(2:1) & $\mathbf{6 . 1 6 7}$ & $\mathbf{1 0 . 0 0}$ & $\mathbf{3 8 . 6 7}$ & $\mathbf{6 . 3 3 3}$ \\
\hline Peat moss +perlite(3:1) & $\mathbf{4 . 5 0 0}$ & $\mathbf{1 1 . 3 3}$ & $\mathbf{3 7 . 6 7}$ & $\mathbf{5 . 3 3 3}$ \\
\hline Peat moss +vermiculite(1:1) & $\mathbf{3 . 6 6 7}$ & $\mathbf{8 . 6 6 7}$ & $\mathbf{3 6 . 3 3}$ & $\mathbf{7 . 0 0 0}$ \\
\hline Peat moss +vermiculite(2:1) & $\mathbf{4 . 0 0 0}$ & $\mathbf{1 0 . 0 0}$ & $\mathbf{3 7 . 0 0}$ & $\mathbf{7 . 6 6 7}$ \\
\hline Peat moss +vermiculite(3:1) & $\mathbf{4 . 0 0 0}$ & $\mathbf{1 0 . 0 0}$ & $\mathbf{5 1 . 6 7}$ & $\mathbf{7 . 0 0 0}$ \\
\hline Peat moss + sand(1:1) & $\mathbf{3 . 5 0 0}$ & $\mathbf{9 . 3 3 3}$ & $\mathbf{5 1 . 3 3}$ & $\mathbf{7 . 6 6 7}$ \\
\hline Peat moss + sand(2:1) & $\mathbf{3 . 6 6 7}$ & $\mathbf{8 . 6 6 7}$ & $\mathbf{5 1 . 3 3}$ & $\mathbf{5 . 3 3 3}$ \\
\hline Peat moss + sand(3:1) & $\mathbf{3 . 8 3 3}$ & $\mathbf{1 0 . 0 0}$ & $\mathbf{5 6 . 0 0}$ & $\mathbf{6 . 6 6 7}$ \\
\hline L.S.D at 5\%level & $\mathbf{1 . 1 5 1}$ & $\mathbf{N . S}$ & $\mathbf{7 . 4 2 2}$ & $\mathbf{1 . 1 5 0}$ \\
\hline
\end{tabular}

Fig.1\&2 Sterilization and development of shoot tips and Sterilization and development of node
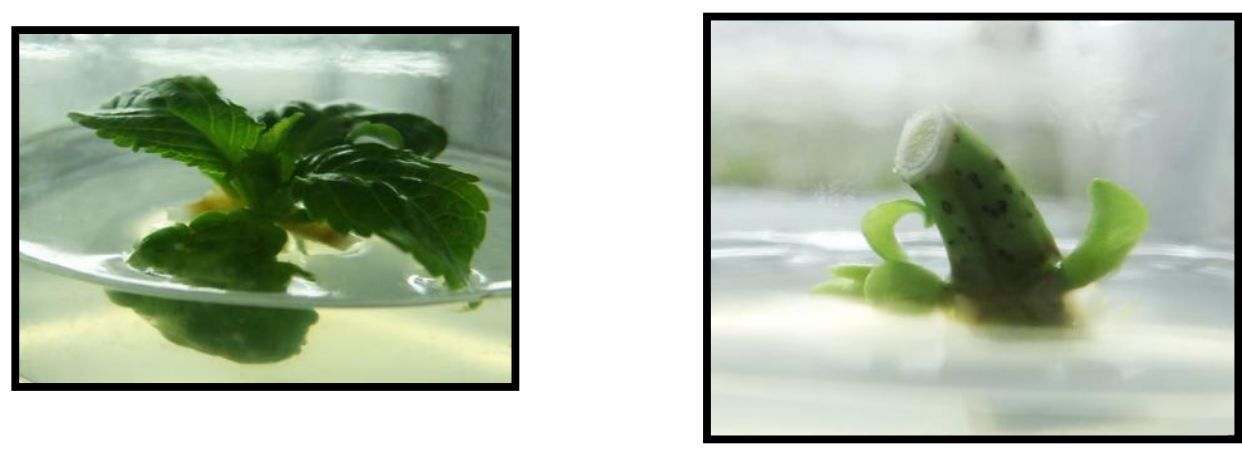

Fig.3 Effect of BA and Kin concentrations on Multiplication stage

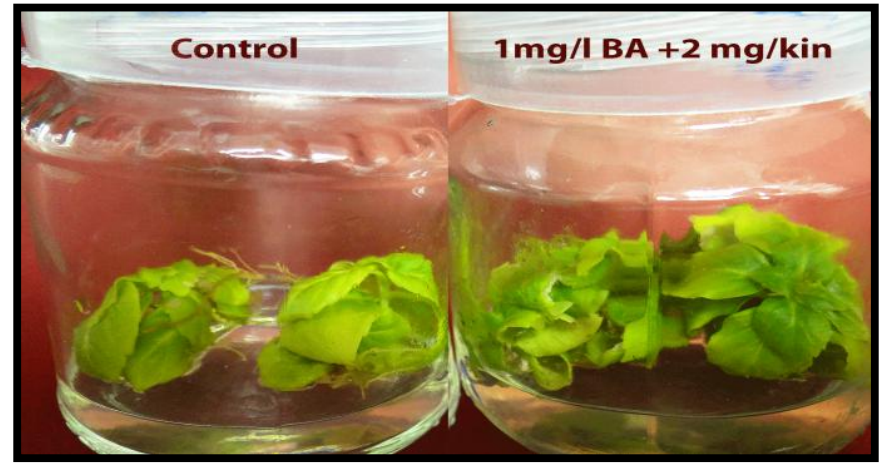


Fig.4 Effect of NAA concentration on growth and development of Hydrangea macrophylla in rooting stage

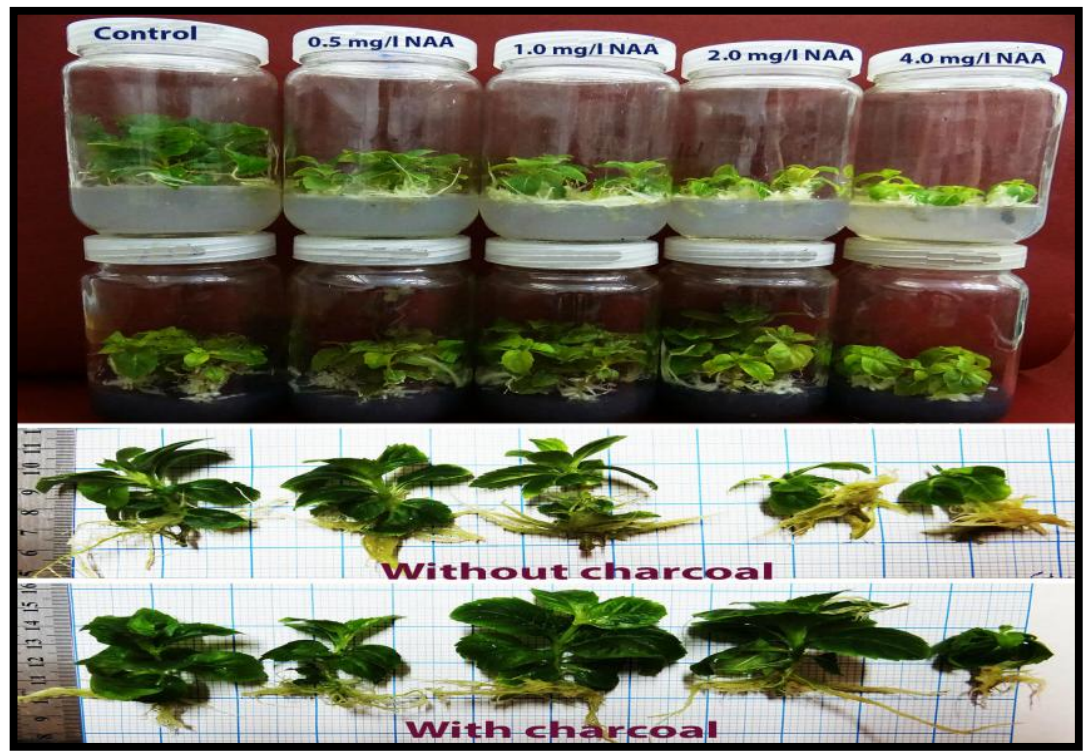

Fig.5 Adaptation of Hydrangea macrophylla plant in greenhouse

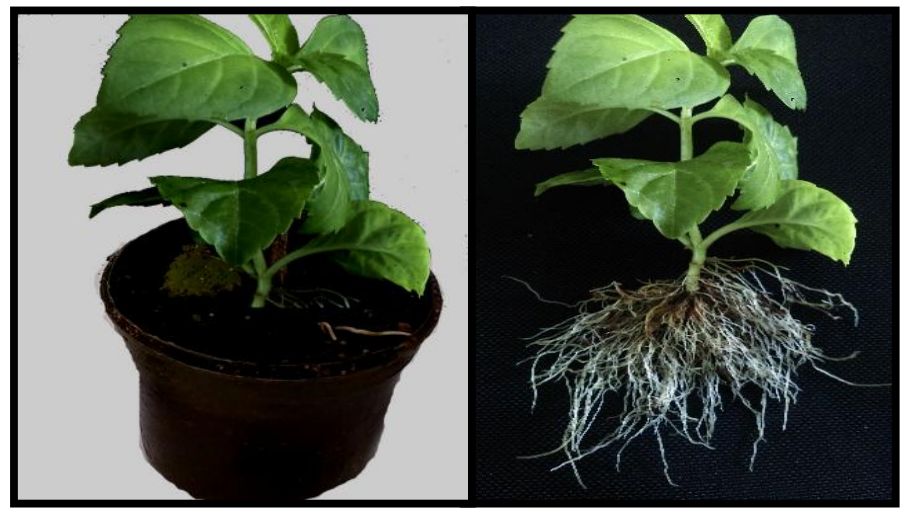

Fig.6 Flowering plant in greenhouse after 10 months

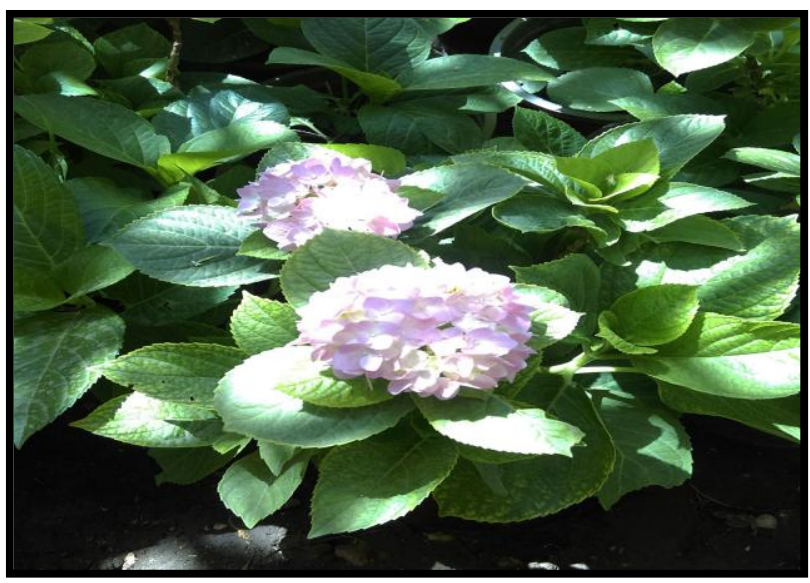


The data shown in table (9) reveal that 1.0 $\mathrm{mg} / \mathrm{l}$ IBA or NAA gave the highest number of roots (4.76), while longest roots $(4.6 \mathrm{~cm})$ was obtained at $2.0 \mathrm{mg} / \mathrm{l}$ IAA. Using medium without charcoal produced the best values of root number and root length, (3.95) and (3.5) respectively. While NAA at $1.0 \mathrm{mg} / \mathrm{l}$ without charcoal gave the highest number of roots (5.4) and the longest root $(4.8 \mathrm{~cm})$ was found at $2.0 \mathrm{mg} / \mathrm{l} \mathrm{IAA}$ without charcoal.

Feng et al., (2011) reported that, these roots was exposed to the air, but had insufficient access to nutrients from the medium, resulting in slow growth. Auxins such as NAA or IBA are usually medium supplemented with 0.5 $\mathrm{mg} / \mathrm{l}$ NAA. When rooted plantlets were transplanted in the greenhouse, they exhibited $100 \%$ survival rate. Sacco et al., (2012) reported that, the highest in vitro rooting percentage was achieved in the presence of NAA $0.5 \mathrm{mg} \mathrm{L}-1$ (100\% rooting).

\section{Acclimatization stage}

\section{Effect of different growing media on adaptation of plantlet Hydrangea macrophylla in greenhouse}

It is clear from the data in table (10) and Fig (4) that the longest plant $(6.17 \mathrm{~cm})$ was achieved when peat moss: perlite $(2: 1 \mathrm{v} / \mathrm{v})$ mixture was used compared with other mixtures, while there were insignificant different between all mixtures on leaf number. The highest number of roots (56.0) was obtained when used peat moss: sand (3: 1 $\mathrm{v} / \mathrm{v})$, on the other hand, the higher mean of root length $(7.67 \mathrm{~cm})$ was fond when two different mixture peat moss: vermiculite $(2: 1$ $\mathrm{v} / \mathrm{v})$ or peat moss: sand $(1: 1 \mathrm{v} / \mathrm{v})$ was used. After 10 months of acclimatization, plants flowered and survival rate of each batch of plants was $100 \%$ in greenhouse Fig (5). Nguyen et al., (1999) reported that, the higher growth and rooting in perlite substrate is due to the superior aeration supporting root growth. Donna and John (2004) recommended that, there was no significant effect of medium on rooting of microshoots. The mean number of roots was 13.6 and the mean percent rooting was $93 \%$. The microshoots acclimatized and rooted well in every medium tested. Only three shoots died during acclimatization: one each in peat-zite, rockwool, and oasis blocks. Feng et al., (2011) reported that, this rooting protocol could reduce costs in commercial Hydrangea micropropagation due to the lower price of perlite relative to agar.

\section{References}

Abou Dahab, T.A.M. 2007. In vitro propagation of Hydrangea macrophylla Thunb. Arab. J. Biotech., 10(1): 161178.

Doil, A., Zhang, R., Schum, A., Serek, M. and Winkelmann, T. 2008. In vitro regeneration and propagation of Hydrangea macrophylla Thunb. 'Nachttgall' Propagation of Ornamental Plants, 8(3): 151-153.

Donna, I., Ledbetter, John, E. 2004. Preece Thidiazuron stimulates adventitious shoot production from Hydrangea quercifolia Bartr. leaf explants. Scientia Horticulturae, 101: 121-126.

Feng Liu, Li-Li Huang and Yang-Li Li. 2011. Shoot organogenesis in leaf explants of Hydrangea macrophylla 'Hyd1' and assessing genetic stability of regenerants using ISSR markers. Plant Cell Tiss. Organ Cult., 104: 111-117.

Jain, S.M. 2002. Feeding the world with induced mutations and biotechnology. Paper presented at Proceeding International Nuclear Conference 2002-Global trends and Perspectives. Seminar 1: agriculture and bioscience. Bangi, Malaysia, 1-14.

Ledbetter, D.I. and Preece, J.E. 2004. 
Thidiazuron stimulates adventitious shoot production from Hydrangea quercifolia Bartr. leaf explants. Scientia Hort., 101: 121-126.

Mstat Development Team. 1989. MSTAT user's guide: a microcomputer program for the design management and analysis of agronomic research experiments, Michigan State University, East Lansing, USA.

Murashige, T. and Skoog, F. 1962. A revised medium for rapid growth and bioassays with tobacco tissue cultures. Physiol. Plant, 15: 473-497.

Nguyen, Q.T., Kozai, T., Nguyen, U.V. 1999. Effects of sucrose concentration, supporting material and number of air exchanges of the vessel on the growth of in vitro coffee plantlets. Plant Cell Tiss. Org. Cult., 58: 51-57.

Orozco-Obando, W. 2005. Developmental And Spatial Characterization Of Flowering In Hydrangea macrophylla. Thunb. Ser, 88p.

Preece, J.E. and Ledbetter, D.I. 2003. The influence of thidiazuron on in vitro shoot proliferation of Oak leaf
Hydrangea. Hydrangea quercifolia Bartr. Acta Hort., 625: 233-236.

Sacco, E., M. Savona, M. Antonetti, A. Grassotti, P.L. Pasqualetto and B. Ruffoni. 2012. In Vitro Propagation and Regeneration of Several Hydrangea Genotypes. Acta Hort., 937: ISHS.

Savona, M., Sacco, E. and Ruffoni, B. 2012. Improving Micropropagation Performances in Hydrangea spp.: Temporary Immersion Shoot Culture and Induction of Morphogenetic Events. Acta Hort., 961: 457-464.

Schiappacasse, F., Moggia, C. and Contreras, R. 2014. Studies with long term storage of cut flowers of Hydrangea macrophylla, IDESIA, Chile, 32(4): 7176.

Sebastian, T.K. and Heurser, C.W. 1987. In vitro propagation of Hydrangea quercifolia Bartr. Scientia Hort., 31: 303-309.

Thomas, K.S and Heuser, C.W. 1987. In vitro propagation of Hydrangea quercifolia Bartr. Scientia Horticulturae, 31: 303309.

\section{How to cite this article:}

Azza M.S. Arafa, A.A. Nower, Samia S. Helme and H.A. Abd-Elaty. 2017. Large Scales of Hydrangea macrophylla Using Tissue Culture Technique. Int.J.Curr.Microbiol.App.Sci. 6(5): 776-778. doi: https://doi.org/10.20546/ijcmas.2017.605.087 